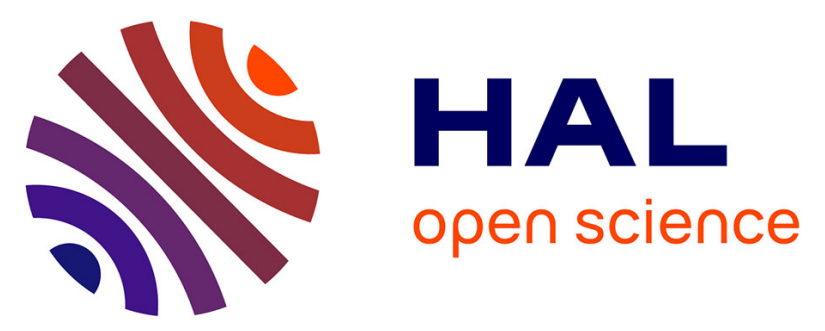

\title{
Hepatic metallothionein concentrations in the golden grey mullet () - relationship with environmental metal concentrations in a metal-contaminated coastal system in Portugal
}

M. Oliveira, I. Ahmad, V.L. Maria, A. Serafim, M.J. Bebianno, M. Pacheco, M.A. Santos

\section{To cite this version:}

M. Oliveira, I. Ahmad, V.L. Maria, A. Serafim, M.J. Bebianno, et al.. Hepatic metallothionein concentrations in the golden grey mullet () - relationship with environmental metal concentrations in a metal-contaminated coastal system in Portugal. Marine Environmental Research, 2010, 69 (4), pp.227. 10.1016/j.marenvres.2009.10.012 . hal-00564779

\author{
HAL Id: hal-00564779 \\ https://hal.science/hal-00564779
}

Submitted on 10 Feb 2011

HAL is a multi-disciplinary open access archive for the deposit and dissemination of scientific research documents, whether they are published or not. The documents may come from teaching and research institutions in France or abroad, or from public or private research centers.
L'archive ouverte pluridisciplinaire HAL, est destinée au dépôt et à la diffusion de documents scientifiques de niveau recherche, publiés ou non, émanant des établissements d'enseignement et de recherche français ou étrangers, des laboratoires publics ou privés. 


\section{Accepted Manuscript}

Hepatic metallothionein concentrations in the golden grey mullet (Liza aurata) - relationship with environmental metal concentrations in a metal-contaminated coastal system in Portugal

M. Oliveira, I. Ahmad, V.L. Maria, A. Serafim, M.J. Bebianno, M. Pacheco, M.A. Santos

PII: S0141-1136(09)00138-X

DOI: 10.1016/j.marenvres.2009.10.012

Reference: MERE 3387

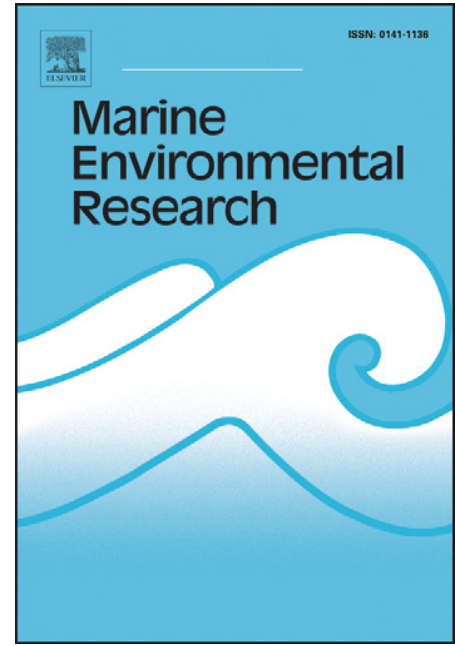

To appear in:

\section{Marine Environmental Research}

Received Date:

24 July 2009

Revised Date:

4 October 2009

Accepted Date:

12 October 2009

Please cite this article as: Oliveira, M., Ahmad, I., Maria, V.L., Serafim, A., Bebianno, M.J., Pacheco, M., Santos, M.A., Hepatic metallothionein concentrations in the golden grey mullet (Liza aurata) - relationship with environmental metal concentrations in a metal-contaminated coastal system in Portugal, Marine Environmental Research (2009), doi: 10.1016/j.marenvres.2009.10.012

This is a PDF file of an unedited manuscript that has been accepted for publication. As a service to our customers we are providing this early version of the manuscript. The manuscript will undergo copyediting, typesetting, and review of the resulting proof before it is published in its final form. Please note that during the production process errors may be discovered which could affect the content, and all legal disclaimers that apply to the journal pertain. 
$1 \quad$ Hepatic metallothionein concentrations in the golden grey mullet (Liza

2 aurata) - relationship with environmental metal concentrations in a metal-

$3 \quad$ contaminated coastal system in Portugal

4

5 M. Oliveira $^{1^{*}}$, I. Ahmad ${ }^{1}$, V.L. Maria ${ }^{2}$, A. Serafim², M.J. Bebianno ${ }^{2}$, M. Pacheco', 6 M.A. Santos ${ }^{1}$

7 1- CESAM \& Department of Biology, University of Aveiro, 3810-193 Aveiro, 8 Portugal

9 Phone: +351-234370965, Fax: +351-234426408

10 * migueloliveira@ua.pt

11

12 2- CIMA \& Faculty of Marine and Environmental Sciences, University of

13 Algarve, Campus Gambelas, 8005-139 Faro, Portugal 


\section{Abstract}

This field survey was designed to assess the environmental metal

16 contamination status of Ria de Aveiro (Portugal). To achieve that goal, the

17 concentrations of $\mathrm{Cd}, \mathrm{Hg}, \mathrm{Cu}$ and $\mathrm{Zn}$ in the sediments and water were assessed

18 and Liza aurata hepatic metallothionein (MT) determined. The relationships

19 between MT and environmental metal concentrations and hydrological factors

20 were examined. Results revealed a wide distribution of metals both in water and

21 sediments throughout the lagoon, mainly at Rio Novo do Principe (RIO) and

22 Laranjo (LAR), at concentrations that may affect biota. MT concentrations were

23 higher at the sites with high metal content (RIO and LAR). A significant positive

24 correlation was found between MT and Cd in the sediments as well as with MT

25 and $\mathrm{Hg}$ and $\mathrm{Cu}$ in the water. Moreover, a negative correlation between MT and

26 salinity was found. Thus, the current data support MT use as a biomarker of

27 metal exposure emphasizing the importance of hydrological parameters in its

28 concentrations. Results suggest the continued monitoring of this lagoon system.

31 Keywords: Liza aurata; Metallothioneins; Cadmium; Copper; Zinc; Mercury;

32 Aquatic pollution 


\section{Introduction}

Metal contamination in aquatic systems is a critical environmental issue due to metal uptake and toxicity in many aquatic organisms, as well as the possibility of their trophic transfer along food chains, eventually reaching humans. Most of these compounds have high affinity for particulate matter and are readily adsorbed onto suspended particles eventually becoming part of sediments where they will remain even after input cessation. Nevertheless, metals may return to the water column or be transferred to biota through physical, chemical and/or biological processes (Schneider and Davey, 1995; Bervoets et al., 2005).

Normal fish cellular metabolism requires essential metals (such as $\mathrm{Cu}$ and $\mathrm{Zn}$ ) which may be taken up from water, food and/or sediment. However, non-essential ones (such as $\mathrm{Cd}$ and $\mathrm{Hg}$ ) may also be absorbed and accumulated in tissues (Canli and Atli, 2003). Thus, environmental pollution monitoring frequently includes assessment of metals in sediment, suspended particulate matter or biota. However, the quantification of environmental or tissue concentrations of a variety of metals does not take into account the biological response or significance of the accumulated metals (Chan, 1995) since metals can accumulate to high levels in organisms and yet be metabolically unavailable, thus unable to induce toxicological effects (Vijver et al., 2004; Banni et al., 2007). Metal exposure generally increases total tissue concentrations of metals. However, the increase of essential metals in some tissues may not be significant due to their regulated accumulation (Atli and Canli, 2008). 
Metallothioneins (MT) are low molecular weight cytosolic proteins rich in

$58 \mathrm{SH}$ groups, known to be over-expressed in organisms from environments with

59 high metal concentrations (Sarkar et al., 2006; Viarengo et al., 2007). In fish,

60 the large amount of MT induction occurs in liver (Canli and Atli, 2003), an organ

61 playing a key role in the storage and inactivation of metals. Considering that MT

62 induction is one of the first detectable signs of the presence of metals (Filipovic

63 and Raspor, 2003; Chesman et al., 2007; Van Campenhout et al., 2008) and

64 the relationship found between metal concentrations in the environment and MT

65 concentrations in fish tissues (Hylland et al., 1992), they have been used to

66 characterize metal contamination in the environment (Chan, 1995; Linde et al.,

67 2001).

68 Ria de Aveiro (Portugal), a coastal lagoon, provides an important habitat

69 for a number of fish species, including the golden grey mullet (Liza aurata). The

70 feeding habits of this species include benthic organisms and detritus, making it

71 particularly adapted to accumulate sediment-associated contaminants and thus

72 an important bio-indicator species. Previous studies concerning this species, in

73 this complex aquatic system, revealed the existence of critical sites within Ria

74 de Aveiro, capable of inducing oxidative and genetic damage (Oliveira et al.,

$752009 a, b, c)$ as well as endocrine disruption (Oliveira et al., 2009d). High

76 concentrations of metals have been detected in this aquatic system (Coelho et

77 al., 2005; Monterroso et al., 2007) and MT inductions as well as inhibitions were

78 observed in L. aurata gill, at some of those critical sites (Oliveira et al., 2009a).

79 Thus, the hepatic MT assessment is highly relevant due to liver central role in

80 metal storage and inactivation. In this perspective, this study assessed the

81 relation between metal concentrations found in water and sediment 
82 compartments of Ria de Aveiro and $L$. aurata hepatic MT. The influence of

83 hydrological factors on MT concentrations was also studied.

\section{Material and Methods}

\subsection{Study Area}

Ria de Aveiro is a lagoon permanently connected to the ocean (Figure 1),

about $45 \mathrm{~km}$ long and $8.5 \mathrm{~km}$ wide. Sampling sites were selected on a

90 geographic distribution basis taking into account the known and supposed

91 sources of metal contamination as well as the selection of a (theoretically)

92 unpolluted reference point. Sampling sites were: Torreira (TOR), an

93 intermediate region of the longest channel (S. Jacinto-Ovar channel), far from

94 the main polluting sources and thus assumed as reference site; Barra (BAR),

95 the initial part of the Mira channel close to the lagoon entrance and subject to

96 considerable naval traffic; Gafanha (GAF) situated in the vicinity of a deep-sea

97 fishing port and dry-docks, also connected with the main channel coming from

98 Aveiro city carrying domestic discharges; Rio Novo do Principe (RIO), located at

99 the terminal area of the Vouga River, $6.5 \mathrm{~km}$ distant from a pulp/paper mill

100 effluent outlet, that discharged to this water course during nearly five decades

101 (until the year 2000); Laranjo (LAR), close to a chlor-alkali plant (6 km), an

102 important source of metal contamination (mainly mercury); Vagos (VAG),

103 located at the terminal part of the Ílhavo channel, receiving municipal and

104 domestic effluents with high concentrations of polycyclic aromatic hydrocarbons 105 (PAHs). 
108 2.2. Sampling: Liza aurata was caught in October 2005, during low tide 109 using a traditional beach-seine net named "chincha". Juvenile specimens were 110 selected on the basis of their size, having an average length of $14.5 \pm 2.5 \mathrm{~cm}$ and

111 weighing $21.6 \pm 3.7 \mathrm{~g}$. Immediately after catching, fish was sacrificed, liver

112 removed and frozen in liquid nitrogen. In the laboratory the samples were stored 113 at $-80^{\circ} \mathrm{C}$ until further treatments.

114 At each sampling site hydrological parameters were assessed (Table I) 115 according APHA (1998) guidelines. Sediments were collected from the surface 116 (15 cm deep) with a grab and stored at $-20^{\circ} \mathrm{C}$ until analysis. Sub-surface water 117 samples were collected by hand, using polyethylene gloves and glass bottles of $1181 \mathrm{~L}$.

\subsection{Metal determination in the water and sediments}

Total metal concentrations in the water samples were determined after

122 liquid-liquid extraction with ammonium pyrrolidine dithiocarbamate (APDC) and

123 methyl isobutyl ketone (MIBK) followed by graphite furnace atomic absorption 124 spectrophotometry (PerkinElmer). This procedure was adopted to pre-

125 concentrate the metals present in the water. Certified standard freshwater 126 reference material (SRM 1643d from NIST) was analyzed to check the accuracy 127 of metal determinations in the water samples.

128 Total metal concentrations in the sediments were determined in the $<63$ $129 \mu \mathrm{m}$ fraction, to minimize the effect of grain size on metal distribution. Samples 130 were manually wet sieved using $63 \mu \mathrm{m}$ nylon sieves and Milli-Q water. After 131 that, this sediment fraction was dried at $40 \stackrel{\circ}{ } \mathrm{C}$. For analysis, approximately $2 \mathrm{~g}$ 
132 of the sediment fraction were accurately weighed and placed into $50 \mathrm{ml}$

133 digestion vessels. After the addition of $5 \mathrm{ml} 69 \%$ nitric acid $\left(\mathrm{HNO}_{3}\right)$, the samples

134 were digested for 2 hours at $80^{\circ} \mathrm{C}$. The digestion mixture was cooled to room

135 temperature and $2 \mathrm{ml} \mathrm{30 \%} \mathrm{hydrogen} \mathrm{peroxide}\left(\mathrm{H}_{2} \mathrm{O}_{2}\right)$ and $3 \mathrm{ml}$ Milli-Q water

136 carefully added. The digestion vessels were heated for another hour. The

137 residue was allowed to cool and diluted with Milli-Q water to a final volume of 50

$138 \mathrm{ml}$. Then samples were allowed to settle down for 24 hours and quantitatively

139 transferred to $50 \mathrm{ml}$ vessels for analysis.

140 The concentrations of $\mathrm{Cd}, \mathrm{Cu}, \mathrm{Hg}$ and $\mathrm{Zn}$ were determined in the 141 supernatant using a Perkin-Elmer atomic absorption spectrophotometer (AAS)

142 model A Analyst 800. All metals except $\mathrm{Cd}$ and $\mathrm{Hg}$ were analyzed by flame

143 atomic absorption spectrophotometry. Cadmium was analysed by an

144 electrothermal atomic absorption spectrometry and mercury by cold vapour 145 atomic spectrophotometry with an automatic hydride generator system.

147 2.4. Metallothionein (MT) content

$148 \quad$ After liver homogenization in $20 \mathrm{mM}$ Tris buffer ( $\mathrm{pH}$ 8.6) containing 150

$149 \mathrm{mM}$ of $\mathrm{NaCl}$, the homogenates were centrifuged 45 minutes at $30000 \mathrm{~g}\left(4^{\circ} \mathrm{C}\right)$.

150 Supernatant aliquots were heat-treated at $80^{\circ} \mathrm{C}$ for 10 minutes and re151 centrifuged at $30000 \mathrm{~g}$ for 45 minutes $\left(4^{\circ} \mathrm{C}\right)$. MT quantification was made by 152 differential pulse polarography (DPP) according to Bebianno and Langston 153 (1989) using a 646VA Processor autolab type II and an ECO Chemie IME663 154 mercury drop electrode. Comparisons of peak heights with those of standard 155 additions of purified rabbit MT enabled MT quantification. Accuracy of the DPP 156 analytical method was obtained by internal calibration using commercial rabbit 
157 liver MT-I. Recovery studies of our cytosols spiked with the MT-I rabbit liver

158 standards revealed recovery rate from 97 to $103 \%$. Results were expressed as $159 \mu \mathrm{g} \mathrm{MT} / \mathrm{g}$ wet weight.

160

161 2.5. Statistical analysis: Results were expressed as means \pm SE 162 (standard error) corresponding to experimental groups of six fish $(n=6)$.

163 Statistical data analysis was done using Statistica software (StatSoft, Inc., 164 Tulsa, OK, USA). Assumptions of normality and homogeneity of data were 165 verified. One way ANOVA was performed in order to assess significant effects, 166 followed by post-hoc Tukey test to signal significant differences between groups 167 (Zar, 1999). The significance of results was ascertained at $\alpha=0.05$. Describing 168 factors were grouped using principal component analysis (PCA), reducing the 169 number of axis without loosing relevant information. Principal components 170 (PCs) having eigenvalues of less than one were discarded, and varimax rotation 171 maximising the loading of a variable on one component was then applied on the 172 retained PCs. The resulting components were then used as independent factors 173 in multiple regression analyses taking MT as the dependent variable. 
174

175

176

177

178

180

181

182

183

184

185

186

187

188

189

190

191

192

193

194

\section{Results}

\subsection{Hydrological Parameters}

The hydrological parameters, expressed in Table I, show differences in terms of turbidity and salinity. Thus, waters were more turbid at LAR and VAG $(0.3 \mathrm{~m})$ and less turbid at BAR $(1.2 \mathrm{~m})$. Salinity at RIO was 21 whereas the other sites displayed values between 29 (LAR) and 34 (GAF and BAR).

\subsection{Metals in Water and Sediment}

The water analyses revealed that RIO displayed significantly higher concentrations of $\mathrm{Hg}, \mathrm{Cu}$ and $\mathrm{Zn}$ than TOR and the other studied sites (with the exception of $\mathrm{Zn}$ concentrations which were not different from VAG) (Table I). Concerning $\mathrm{Cd}$, the highest concentrations in water were found at LAR (significantly higher than in all other sites). BAR displayed lower concentrations of $\mathrm{Cd}, \mathrm{Hg}, \mathrm{Cu}$ and $\mathrm{Zn}$ when compared to TOR (though not significantly in the case of $\mathrm{Cd}$ ). The metal concentrations in water at GAF were only significantly different (higher) from TOR in the case of $\mathrm{Hg}$. At LAR, the concentrations of all the analysed metals were significantly higher than TOR whereas VAG displayed lower $\mathrm{Hg}$ and $\mathrm{Cu}$ and higher $\mathrm{Zn}$ concentrations in water.

Concerning the concentrations of metals in the sediments (Table I), the highest concentrations of $\mathrm{Hg}, \mathrm{Cu}$ and $\mathrm{Zn}$ were found at LAR (significantly higher than all other studied sites). Concerning $\mathrm{Cd}$, the highest concentrations in the sediments were found at RIO (significantly higher than all other studied sites) and LAR (significantly higher than TOR, BAR, GAF and VAG). Hg concentrations in sediments at BAR and RIO were also higher than in TOR, GAF and VAG. The concentrations of $\mathrm{Cu}$ in sediments at $\mathrm{RIO}$ were also 
199 significantly higher than TOR whereas $\mathrm{Zn}$ concentrations at BAR, GAF and

200 VAG were significantly lower than TOR.

201

202

\subsection{Metallothionein}

203

RIO displayed significantly higher MT concentration when compared to all studied sites (Figure 2). Thus, compared to TOR, MT concentration was 256\% higher at RIO. LAR also displayed significantly higher MT concentration than TOR (107\%), BAR, GAF, and VAG. At VAG, MT concentration was significantly lower than TOR (74\%).

\subsection{Principal Component Analysis and Linear Multiple Regression}

Three principal components were defined as explaining the major amount of total variance $(89.97 \%)$ of the assessed parameters (except MT)

212 (Table II). Thus, the first component which includes salinity, temperature, Cd in

213 the sediments, $\mathrm{Hg}, \mathrm{Cu}$ and $\mathrm{Zn}$ in the water explains $36.19 \%$ of total variance.

214 The second component including $\mathrm{Hg}, \mathrm{Zn}$ and $\mathrm{Cu}$ in the sediments and $\mathrm{Cd}$ in the 215 water, explains $28.84 \%$. The third components including turbidity, $\mathrm{pH}$ and 216 dissolved oxygen explain $24.93 \%$ of variance. According to the multiple

217 regression analyses the first two factors account for $98.2 \%$ of MT variability and 218 the first factor alone is responsible for $77 \%$. Cd in the sediments, $\mathrm{Hg}$ and $\mathrm{Cu}$ in 219 the water and salinity displayed the strongest (significant) correlations with MT 220 (Figure 3). 
224

225

226

227

228

229

230

231

232

233

234

235

236

237

238

240

241

242

243

244

246

247

248

\section{Discussion}

Biological factors such as age, sex, reproductive status as well as hormone levels may influence MT induction, increasing response variability (Hamza-Chaffai et al., 1995). Moreover, it was demonstrated in L. aurata that total length, body weight and age are biometric parameters correlated with MT (Filipovic and Raspor, 2003). In this perspective, L. aurata specimens selected for the current study were juvenile with the same age and reproductively quiescent and the stress of capture and handling was reduced as much as possible.

\subsection{Metal concentrations}

Metals mobility and reactivity in estuaries are highly influenced by the organic matter content, salinity, redox conditions and pH (Sauve et al., 2000; Liang and Wong, 2003). Sediment metal concentrations usually exceed those in the water column. However, metals bound to the sediment may enrich interstitial and overlying waters with metals (Bryan and Langston, 1992) upon changes in the environment. In the current study, the concentrations of two of the most dangerous metals to aquatic organisms, $\mathrm{Cd}$ and $\mathrm{Hg}$, listed in the priority substances of EU Directive 2008/105/EC, as well as two essential metals, $\mathrm{Cu}$ and $\mathrm{Zn}$, that in high concentrations may also induce toxic effects in aquatic organisms (Oliveira et al., 2004) were quantified in the water and sediments of Ria de Aveiro. The studied metals displayed a distribution throughout the lagoon. Zn displayed the highest concentrations in sediments, followed by $\mathrm{Cu}, \mathrm{Cd}$ and $\mathrm{Hg}$. The highest concentrations of metals in the sediments were found in LAR (for $\mathrm{Zn}, \mathrm{Cu}$ and $\mathrm{Hg}$ ) and $\mathrm{RIO}$ (for $\mathrm{Cd}$ ). At RIO, 
249 LAR and BAR $\mathrm{Hg}$ was higher than the defined Water Framework Directive

250 environmental quality standard for sediments $\left(0.36 \mu \mathrm{g} \cdot \mathrm{g}^{-1}\right)$. Most of the available

251 studies on metals concentrations in Ria de Aveiro focused on $\mathrm{Hg}$ contamination

252 in LAR, due to the emission history of a chlor-alkali plant (Ramalhosa et al.,

253 2005). Thus, at LAR area, the concentration of $\mathrm{Hg}$ detected in the sediments

254 reached values as high as $51.7 \mu \mathrm{g} \cdot \mathrm{g}^{-1}$ (Coelho et al., 2005). In the current study,

255 the highest concentration of $\mathrm{Hg}$ in the sediments was found in LAR $\left(2.33 \mu \mathrm{g} \cdot \mathrm{g}^{-1}\right)$

256 and was within the same order of magnitude of other studies (Pereira et al.,

257 2006; Ramalhosa et al., 2006). The present data also revealed considerable Hg

258 in the sediments of BAR and RIO (0.88 and $0.86 \mu \mathrm{g} \cdot \mathrm{g}^{-1}$ respectively), probably

259 due to tidal export from Laranjo area (Pereira et al., 1998) and/or from nonpoint

260 sources. Despite most studies on metal concentrations at LAR focused on $\mathrm{Hg}$,

261 elevated concentrations of other metals were also found there by Monterroso et

262 al. (2007). The concentrations of $\mathrm{Cd}$, $\mathrm{Cu}$ and $\mathrm{Zn}$ found in the current study at

263 LAR sediments were similar to those found by Monterroso et al. (2007).

264 The metal concentrations in water reported in the current study can only

265 be compared with other studies in Ria de Aveiro in terms of $\mathrm{Hg}$ in LAR, being in

266 the same order of magnitude of previously reported concentrations (Ramalhosa

267 et al., 2006; Guilherme et al., 2008). Unlike sediments which displayed higher

$268 \mathrm{Hg}, \mathrm{Cu}$ and $\mathrm{Zn}$ concentrations at LAR, in water, RIO displayed the highest

269 concentrations of $\mathrm{Hg}, \mathrm{Cu}$ and $\mathrm{Zn}$. Another clear difference to sediments was

270 found in BAR that displayed very low $\mathrm{Hg}$ concentrations in water (below

271 detection limit). Moreover, Cd concentrations at all studied sites were above the

272 defined environmental quality standard for water of Water Framework Directive

$273\left(0.21 \mu \mathrm{g} \cdot \mathrm{g}^{-1}\right)$. 
One of the outstanding difficulties encountered in environmental impact

275 assessments is to determine the biological significance of contaminants

276 (Langston et al., 2002). In this perspective numerical quality guidelines have

277 been developed, identifying concentrations of chemicals of potential concern

278 that may cause or contribute to adverse effects (MacDonald et al., 2000).

279 However, its use should be carefully interpreted since factors like organic

280 matter, grain size and percentage of clay may be confounding elements for

281 direct comparison. Nevertheless, the comparison of the present metal data with

282 some quality guidelines (Long et al., 1995; MacDonald et al., 1996) reveals that

283 the concentrations detected in the sediments mainly at LAR and RIO and BAR

284 may lead to frequent adverse effects in aquatic organisms. The concentrations

285 of metals in the water are highly dynamic, being influenced by abiotic factors

286 among which the water flow. Nevertheless, the water concentrations of $\mathrm{Hg}$ at

$287 \mathrm{RIO}$ as well as $\mathrm{Cu}$ at RIO, LAR and GAF, can lead to damage in aquatic

288 species considering they were higher than the US EPA (2006) estimated

289 highest concentration to which an aquatic community can be exposed

290 indefinitely without resulting in an unacceptable effect.

291 The bioavailability of a metal does not necessarily lead to harmful effects

292 in organisms since they evolved defence mechanisms which allow them to

293 decrease metal reactivity in cells. Among those defences, MT are considered as

294 the most suitable biomarker for $\mathrm{Cd}, \mathrm{Cu}, \mathrm{Zn}$ and $\mathrm{Hg}$ exposure (Hylland et al.,

295 1998), reflecting bioavailability and tissue pharmacokinetics of metal uptake

296 (Handy et al., 2003). In this perspective, the study of L. aurata liver MT

297 becomes highly relevant, taking into account that liver is the main metal

298 accumulating organ in this species (Usero et al., 2003). However, despite the 
299 known presence of metals in Ria de Aveiro and the suitability of fish MT as

300 biomarkers of exposure to metals, the studies focusing on environmental metal

301 concentrations and fish MT concentrations are very scarce.

302 Measurable (constitutive) concentrations of MT are always expected

303 even in uncontaminated sites, due to MT homeostatic role in transferring

304 essential elements to and from metalloproteins. The observed MT

305 concentrations ranged from 45.6 to 627.7 ( $\mu \mathrm{g} \cdot \mathrm{g}^{-1}$ wet weight), being in the same

306 order of magnitude of the MT concentrations found in other species. For

307 example, Zorita et al. (2008) found MT concentrations in red mullets (Mullus

308 barbatus) between 100 and 710 ( $\mu \mathrm{g} \cdot \mathrm{g}^{-1}$ wet weight). However, the current

309 hepatic MT concentrations were much lower than in L. aurata from Eastern

310 Adriatic coastal zone (2320 $\mu \mathrm{g} \cdot \mathrm{g}^{-1}$ wet weight) (Filipovic and Raspor, 2003).

311 Differences may be linked with different age, weight and size of the surveyed

312 specimens. Supporting this hypothesis, a positive and statistically significant

313 correlation between L. aurata total length and body weight with MT and metals

314 in liver cytosol was found by the authors (Filipovic and Raspor, 2003).

315 In the current study, MT concentrations were higher at the sites

316 displaying the highest metal concentrations, supporting its usefulness in

317 environmental monitoring even in complex environments where interference of

318 other xenobiotics can be found. MT use as biomarker of response to metals

319 exposure is more sensitive to metals such $\mathrm{Cd}$ and $\mathrm{Hg}$ and to a much lower

320 extent to essential metals (Olsvik et al., 2001; Banni et al., 2007; Atli and Canli,

321 2008;) which have their cytosolic concentrations closely regulated through

322 homeostatic mechanisms often binding to structures other than MT (Laflamme

323 et al., 2000; Langston et al., 2002; Linde et al., 2005). In this perspective, other 
324 sulfhydryl group containing substances such as GSH may also play an

325 important role in cellular protection against metal cytotoxicity (Viarengo and

326 Nott, 1993; Oliveira et al., 2004). Nevertheless, a high positive correlation of MT

327 and $\mathrm{Cu}$ cytosolic concentrations was found in liver of L. aurata (Filipovic and

328 Raspor, 2003). Moreover, considering the complex environment that is an

329 estuary, the combined effects of other xenobiotics should also be considered as

330 demonstrated by Romeo et al. (1997) and van den Hurk et al. (2000). Despite

331 the demonstration that simultaneous exposure to metals such as Cd and PAHs

332 may yield higher MT concentrations than metal exposure alone, our study

333 clearly shows MT induction in environments with high metal concentrations

334 (RIO and LAR) and low concentrations in sites with low metal concentrations

335 (TOR, BAR and VAG). The previous (and only available study) on MT

336 concentrations of $L$. aurata caught at Ria de Aveiro (Oliveira et al., 2009a),

337 showed higher gill MT concentrations at LAR and suggested that this site was

338 the most contaminated with metals. Moreover, no significant differences to TOR

339 were found in that study in MT concentrations from RIO. These results seem to

340 confirm that the hepatic MT concentrations are more reliable to the

341 environmental metal contamination assessment than gill MT.

\subsection{Relation between MTs and abiotic factors}

The multiple regression analyses showed that the assessed

345 metals and hydrological parameters grouped in components 1 and 2 could 346 explain $98.2 \%$ of the variability of MTs. Thus, salinity, temperature, Cd in the

347 sediments $\mathrm{Hg}, \mathrm{Cu}$ and $\mathrm{Zn}$ in water were responsible for $77 \%$ of MT variability.

348 Of these parameters, linear regression analyses signalled as more correlated

$349 \mathrm{Cd}$ in the sediments, $\mathrm{Cu}$ and $\mathrm{Hg}$ in water and salinity (inversely). It has been 
350 generally accepted that the toxicity of certain metals to aquatic animals is

351 influenced by ambient salinity. Thus, metals are usually more toxic at low 352 salinities probably associated with increased uptake rates, as a result of an

353 increase in free metal ion concentrations. In this perspective, a highly significant

354 negative correlation between MT and salinity was also found in the Brazilian

355 flounder (Paralichthys orbignyanus) collected from an estuary (Amado et al.,

356 2006). Thus, a determinant role of salinity in the metal bioavailability can be on

357 the basis of the negative correlation currently found between that abiotic

358 parameter and hepatic MT. However, a definitive linkage between these

359 variables is complicated by the occurrence of different patterns of contamination

360 and salinity levels in the sites under comparison.

361 Thus, the usefulness of $L$. aurata hepatic MT as biomarkers of metal 362 exposure was demonstrated in fish caught at Ria de Aveiro despite the known 363 ability of other xenobiotics to interfere in MT concentrations and the known 364 existence of different type of xenobiotics in Ria de Aveiro.

366

367 5. Conclusions

368 High concentrations of metals can be found in the sediments and water

369 of Ria de Aveiro which may result in pernicious effects to aquatic organisms.

370 The highest concentrations of metals in the sediments and water were found in

371 LAR and RIO. Thus, in sediments, LAR for $\mathrm{Zn}, \mathrm{Cu}$ and $\mathrm{Hg}$ and $\mathrm{RIO}$ for $\mathrm{Cd}$ 372 displayed the highest concentrations. In water, RIO displayed the highest 373 concentrations of $\mathrm{Hg}, \mathrm{Cu}$ and $\mathrm{Zn}$ and LAR the highest concentrations of $\mathrm{Cd}$. 
L. aurata hepatic MT concentrations can be ranked as:

$375 \mathrm{RIO}>\mathrm{LAR}>\mathrm{GAF}>\mathrm{TOR}>\mathrm{BAR}>\mathrm{VAG}$. The highest hepatic MT concentrations

376 displayed at the most contaminated sites (RIO and LAR) reveal a strong $L$.

377 aurata defence capacity against metal toxicity.

378 The correlation between environmental concentrations of metals and $L$.

379 aurata hepatic MT, supports MT applicability as a biomarker of metal pollution in

380 contaminated aquatic systems, though the influence of abiotic factors namely

381 salinity should be considered.

382 The results of the current study suggest continued monitoring of Ria de 383 Aveiro.

6. Acknowledgments

Financial support from Fundação para a Ciência e Tecnologia - FCT

387 (Government of Portugal) provided through POCI/MAR/61195/2004, 388 SFRH/BD/27584/2006, SFRH/BPD/26970/2006, SFRH/BPD/34326/2006 and

389 by CESAM - Aveiro University Research Institute are gratefully acknowledged.

\section{References}

Amado, L.L., Robaldo, R.B., Geracitano, L., Monserrat, J.M., Bianchini, A., 2006. Biomarkers of exposure and effect in the Brazilian flounder Paralichthys orbignyanus (Teleostei: Paralichthyidae) from the Patos Lagoon estuary (Southern Brazil). Marine Pollution Bulletin 52, 207-213.

Atli, G., Canli, M., 2008. Responses of metallothionein and reduced glutathione in a freshwater fish Oreochromis niloticus following metal exposures. Environmental Toxicology and Pharmacology 25, 33-38.

Banni, M., Dondero, F., Jebali, J., Guerbej, H., Boussetta, H., Viarengo, A., 2007. Assessment of heavy metal contamination using real-time PCR analysis of mussel metallothionein $\mathrm{mt} 10$ and $\mathrm{mt} 20$ expression: a validation along the Tunisian coast. Biomarkers 12, 369 - 383. 
Bebianno, M.J., Langston, W.J., 1989. Quantification of metallothioneins in marine invertebrates using differential pulse polarography. Portugaliae Electrochimica Acta 7, 511-524.

Bervoets, L., Voets, J., Covaci, A., Chu, S., Qadah, D., Smolders, R., Schepens, P., Blust, R., 2005. Use of transplanted zebra mussels (Dreissena polymorpha) to assess the bioavailability of microcontaminants in Flemish surface waters. Environmental Science \& Technology 39, 1492-1505.

Bryan, G.W., Langston, W.J., 1992. Bioavailability, accumulation and effects of heavy metals in sediments with special reference to United Kingdom estuaries - a review. Environmental Pollution 76, 89-131.

Canli, M., Atli, G., 2003. The relationships between heavy metal $(\mathrm{Cd}, \mathrm{Cr}, \mathrm{Cu}, \mathrm{Fe}, \mathrm{Pb}$, $\mathrm{Zn})$ levels and the size of six Mediterranean fish species. Environmental Pollution 121, 129-136.

Chan, K.M., 1995. Metallothionein: Potential biomarker for monitoring heavy metal pollution in fish around Hong Kong. Marine Pollution Bulletin 31, 411-415.

Chesman, B.S., O'Hara, S., Burt, G.R., Langston, W.J., 2007. Hepatic metallothionein and total oxyradical scavenging capacity in Atlantic cod Gadus morhua caged in open sea contamination gradients. Aquatic Toxicology 84, 310-320.

Coelho, J.P., Pereira, M.E., Duarte, A., Pardal, M.A., 2005. Macroalgae response to a mercury contamination gradient in a temperate coastal lagoon (Ria de Aveiro, Portugal). Estuarine Coastal and Shelf Science 65, 492-500.

EU Directive 2008/105/EC of the European Parliament and of the Council of the 16 December 2008 on environmental quality standards in the field of water policy, amending and subsequently repealing Council Directives 82/176/EEC, 83/513/ EEC, 84/156/EEC, 84/491/EEC, 86/280/EEC and amending Directive 2000/60/EC of the European Parliament and of the Council. Off. J. Eur. Comm. L 348/84.

Filipovic, V., Raspor, B., 2003. Metallothionein and metal levels in cytosol of liver, kidney and brain in relation to growth parameters of Mullus surmuletus and Liza aurata from the Eastern Adriatic Sea. Water Research 37, 3253-3262.

Guilherme, S., Válega, M., Pereira, M.E., Santos, M.A., Pacheco, M., 2008. Erythrocytic nuclear abnormalities in wild and caged fish (Liza aurata) along an environmental mercury contamination gradient. Ecotoxicology and Environmental Safety 70, 411-421.

Hamza-Chaffai, A., Cosson, R.P., Amiard-Triquet, C., El Abed, A., 1995. Physicochemical forms of storage of metals $(\mathrm{Cd}, \mathrm{Cu}$ and $\mathrm{Zn})$ and metallothionein-like proteins in gills and liver of marine fish from the Tunisian coast: ecotoxicological consequences. Comparative Biochemistry and Physiology Part C: Pharmacology, Toxicology and Endocrinology 111, 329-341.

Handy, R.D., Galloway, T.S., Depledge, M.H., 2003. A proposal for the use of biomarkers for the assessment of chronic pollution and in regulatory toxicology. Ecotoxicology 12, 331-343.

Hylland, K., Haux, C., Hogstrand, C., 1992. Hepatic metallothionein and heavy-metals in dab Limanda limanda from the German Bight. Marine Ecology-Progress Series 91, 89-96.

Hylland, K., Nissen-Lie, T., Christensen, P.G., Sandvik, M., 1998. Natural modulation of hepatic metallothionein and cytochrome P4501A in flounder, Platichthys flesus L. Marine Environmental Research 46, 51-55.

Laflamme, J.S., Couillard, Y., Campbell, P.G.C., Hontela, A., 2000. Interrenal metallothionein and cortisol secretion in relation to $\mathrm{Cd}, \mathrm{Cu}$, and $\mathrm{Zn}$ exposure in 
yellow perch, Perca flavescens, from Abitibi lakes. Canadian Journal of Fisheries and Aquatic Sciences 57, 1692-1700.

Langston, W.J., Chesman, B.S., Burt, G.R., Pope, N.D., McEvoy, J., 2002. Metallothionein in liver of eels Anguilla anguilla from the Thames Estuary: an indicator of environmental quality? Marine Environmental Research 53, 263293.

Liang, Y., Wong, M.H., 2003. Spatial and temporal organic and heavy metal pollution at Mai Po Marshes Nature Reserve, Hong Kong. Chemosphere 52, 1647-1658.

Linde, A.R., Klein, D., Summer, K.H., 2005. Phenomenon of hepatic overload of copper in Mugil cephalus: Role of metallothionein and patterns of copper cellular distribution. Basic \& Clinical Pharmacology \& Toxicology 97, 230-235.

Linde, A.R., Sánchez-Galán, S., Vallés-Mota, P., García-Vázquez, E., 2001. Metallothionein as bioindicator of freshwater metal pollution: European eel and brown trout. Ecotoxicology and Environmental Safety 49, 60-63.

Long, E.R., Macdonald, D.D., Smith, S.L., Calder, F.D., 1995. Incidence of adverse biological effects within ranges of chemical concentrations in marine and estuarine sediments. Environmental Management 19, 81-97.

MacDonald, D.D., Carr, R.S., Calder, F.D., Long, E.R., Ingersoll, C.G., 1996. Development and evaluation of sediment quality guidelines for Florida coastal waters. Ecotoxicology 5, 253-278.

MacDonald, D.D., Ingersoll, C.G., Berger, T.A., 2000. Development and evaluation of consensus-based sediment quality guidelines for freshwater ecosystems. Archives of Environmental Contamination and Toxicology 39, 20-31.

Monterroso, P., Pato, P., Pereira, M.E., Millward, G.E., Vale, C., Duarte, A., 2007. Metal-contaminated sediments in a semi-closed basin: Implications for recovery. Estuarine Coastal and Shelf Science 71, 148-158.

Oliveira, M., Ahmad, I., Maria, V.L., Pacheco, M., Santos, M.A., 2009b. Monitoring pollution of coastal lagoon using Liza aurata kidney oxidative stress and genetic endpoints: An integrated biomarker approach. Submitted.

Oliveira, M., Maria, V.L., Ahmad, I., Serafim, A., Bebianno, M.J., Pacheco, M., Santos, M.A., 2009a. Contamination assessment of a coastal lagoon (Ria de Aveiro, Portugal) using defence and damage biochemical indicators in gill of Liza aurata - An integrated biomarker approach. Environmental Pollution 157, 959967.

Oliveira, M., Maria, V.L., Ahmad, I., Serafim, A., M.J., B., Pacheco, M., Santos, M.A., 2009d. Fish thyroidal and stress responses in contamination monitoring - An integrated biomarker approach. Submitted.

Oliveira, M., Maria, V.L., Ahmad, I., Teles, M., Serafim, A., M.J., B., Pacheco, M., Santos, M.A., 2009c. Golden grey mullet and sea bass oxidative DNA damage and clastogenic/aneugenic responses in a contaminated coastal Lagoon. Submitted.

Oliveira, M., Santos, M.A., Pacheco, M., 2004. Glutathione protects heavy metalinduced inhibition of hepatic microsomal ethoxyresorufin O-deethylase activity in Dicentrarchus labrax L. Ecotoxicology and Environmental Safety 58, 379385.

Olsvik, P.A., Hindar, K., Zachariassen, K.E., Andersen, R.A., 2001. Brown trout (Salmo trutta) metallothioneins as biomarkers for metal exposure in two Norwegian rivers. Biomarkers 6, $274-288$.

Pereira, E., Abreu, S.N., Coelho, J.P., Lopes, C.B., Pardal, M.A., Vale, C., Duarte, A.C., 2006. Seasonal fluctuations of tissue mercury contents in the European shore 
crab Carcinus maenas from low and high contamination areas (Ria de Aveiro, Portugal). Marine Pollution Bulletin 52, 1450-1457.

Pereira, M.E., Duarte, A.C., Millward, G.E., Abreu, S.N., Vale, C., 1998. An estimation of industrial mercury stored in sediments of a confined area of the Lagoon of Aveiro (Portugal). Water Science and Technology 37, 125-130.

Ramalhosa, E., Pato, P., Monterroso, P., Pereira, E., Vale, C., Duarte, A.C., 2006. Accumulation versus remobilization of mercury in sediments of a contaminated lagoon. Marine Pollution Bulletin 52, 353-356.

Ramalhosa, E., Pereira, E., Vale, C., Válega, M., Duarte, A.C., 2005. Distribution of mercury in the upper sediments from a polluted area (Ria de aveiro, Portugal). Marine Pollution Bulletin 50, 682-686.

Romeo, M., Cosson, R.P., Gnassia-Barelli, M., Risso, C., Stien, X., Lafaurie, M., 1997. Metallothionein determination in the liver of the sea bass Dicentrarchus labrax treated with copper and B(a)P. Marine Environmental Research 44, 275-284.

Sarkar, A., Ray, D., Shrivastava, A., Sarker, S., 2006. Molecular Biomarkers: Their significance and application in marine pollution monitoring. Ecotoxicology 15, 333-340.

Sauve, S., Hendershot, W., Allen, H.E., 2000. Solid-solution partitioning of metals in contaminated soils: Dependence on $\mathrm{pH}$, total metal burden, and organic matter. Environmental Science \& Technology 34, 1125-1131.

Schneider, P.M., Davey, S.B., 1995. Sediment contaminants off the coast of Sydney, Australia: A model for their distribution. Marine Pollution Bulletin 31, 262-272.

US EPA (United States Environmental Protection Agency), 2002. National recommended water quality criteria. Office of Science and Technology.

Usero, J., Izquierdo, C., Morillo, J., Gracia, I., 2003. Heavy metals in fish (Solea vulgaris, Anguilla anguilla and Liza aurata) from salt marshes on the southern Atlantic coast of Spain. Environment International 1 29, 949-956.

Van Campenhout, K., Infante, H.G., Goemans, G., Belpaire, C., Adams, F., Blust, R., Bervoets, L., 2008. A field survey of metal binding to metallothionein and other cytosolic ligands in liver of eels using an on-line isotope dilution method in combination with size exclusion (SE) high pressure liquid chromatography (HPLC) coupled to Inductively Coupled Plasma time-of-flight Mass Spectrometry (ICP-TOFMS). Science of The Total Environment 394, 379-389.

van den Hurk, P., Faisal, M., Roberts Jr, M.H., 2000. Interactive effects of cadmium and benzo[a]pyrene on metallothionein induction in mummichog (Fundulus heteroclitus). Marine Environmental Research 50, 83-87.

Viarengo, A., Lowe, D., Bolognesi, C., Fabbri, E., Koehler, A., 2007. The use of biomarkers in biomonitoring: A 2-tier approach assessing the level of pollutantinduced stress syndrome in sentinel organisms. Comparative Biochemistry and Physiology Part C: Toxicology \& Pharmacology 146, 281-300.

Viarengo, A., Nott, J.A., 1993. Mechanisms of heavy metal cation homeostasis in marine invertebrates. Comp. Biochem. Phys. C 104, 355-372.

Vijver, M.G., van Gestel, C.A.M., Lanno, R.P., van Straalen, N.M., Peijnenburg, W.J.G.M., 2004. Internal metal sequestration and its ecotoxicological relevance: a review. Environmental Science \& Technology 38, 4705-4712.

Zar, J.H., 1999. Biostatistical Analysis, Fourth Edition ed. Prentice Hall, New Jersey.

Zorita, I., Ortiz-Zarragoitia, M., Apraiz, I., Cancio, I., Orbea, A., Soto, M., Marigómez, I., Cajaraville, M.P., 2008. Assessment of biological effects of environmental pollution along the NW Mediterranean Sea using red mullets as sentinel organisms. Environmental Pollution 153, 157-168. 
Figure 1 - Map of the sampling sites (a) in the Ria de Aveiro. The

556 respective coordinates (latitude, longitude) are: reference site - Torreira (TOR)

$557-40^{\circ} 44^{\prime} 02 \mathrm{~N}, 008^{\circ} 41^{\prime} 44 \mathrm{~W} ;$ Barra $(\mathrm{BAR})-40^{\circ} 37^{\prime} 42 \mathrm{~N}, 008^{\circ} 44^{\prime} 35 \mathrm{~W}$;

558 Gafanha (GAF) - 4038'38 N, 00841'42 W; Rio Novo do Principe (RIO) -

559 4041'08 N, 00839'41 W; Laranjo (LAR) - 4043'30 N, 00837'43 W; Vagos

560 (VAG) $-40^{\circ} 33^{\prime} 59 \mathrm{~N}, 008^{\circ} 40^{\prime} 55 \mathrm{~W}$

561

562 Table I - Environmental characterization: hydrological parameters and

563 metals concentrations in water and sediments. Distinct letters indicate

564 significant differences between sites $(p<0.05)$.

565

566 Figure 2 - Hepatic metallothionein (MT) of L. aurata collected at different

567 sites in Ria de Aveiro. Values represent mean \pm standard error $(n=6)$. Distinct

568 letters indicate significant differences between sites $(p<0.05)$.

569

570 Table II - Results of the Principal Component Analysis (PCA) on the

571 dataset: coefficients of the eigenvectors (loadings of the original variables) in

572 the linear combination of variates from which the PCs are computed (loadings

$573<0.25$ were omitted)

575 Figure 3 - Correlation between L. aurata hepatic MT and A) Salinity; B)

576 Cu in water; C) $\mathrm{Hg}$ in water; D) Cd in the sediments. Statistical significance and

577 correlation coefficient are represented by $p$ and $r$, respectively. 
Figure 1

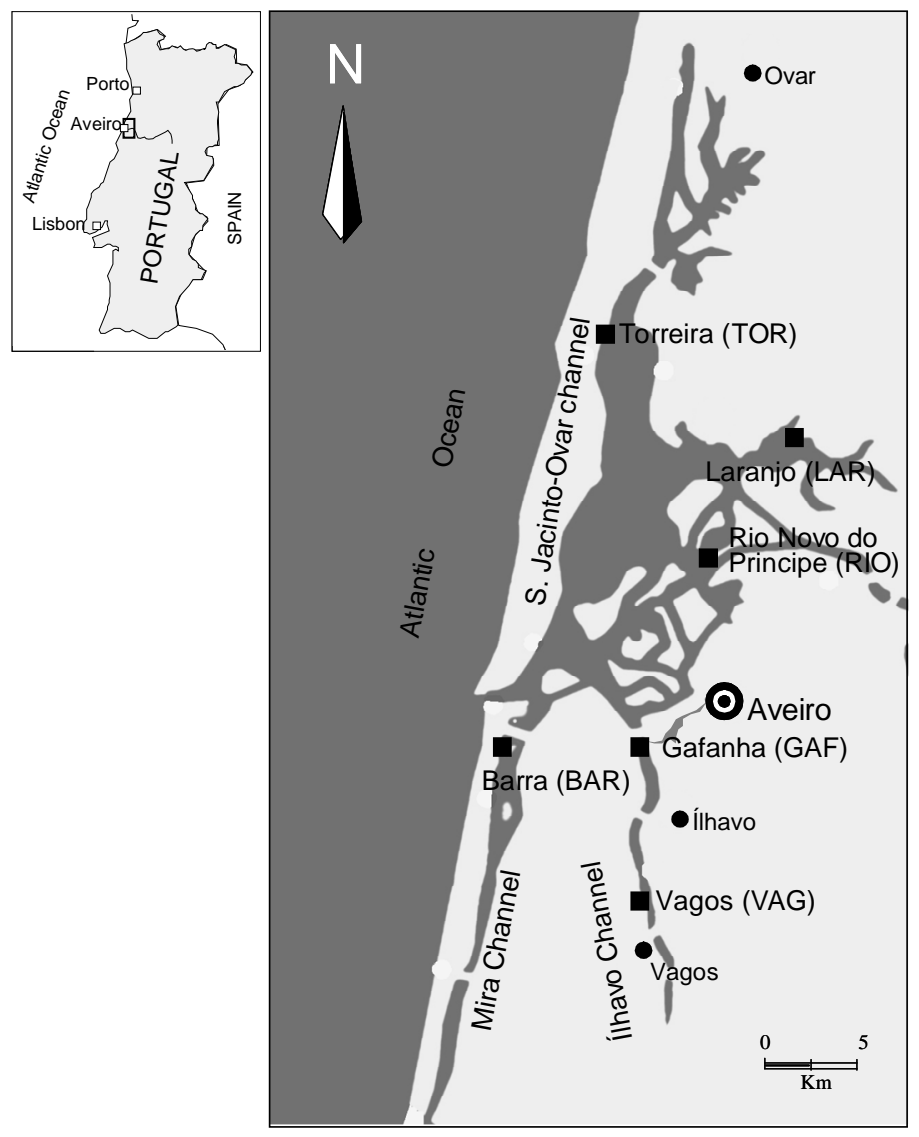


Figure 2

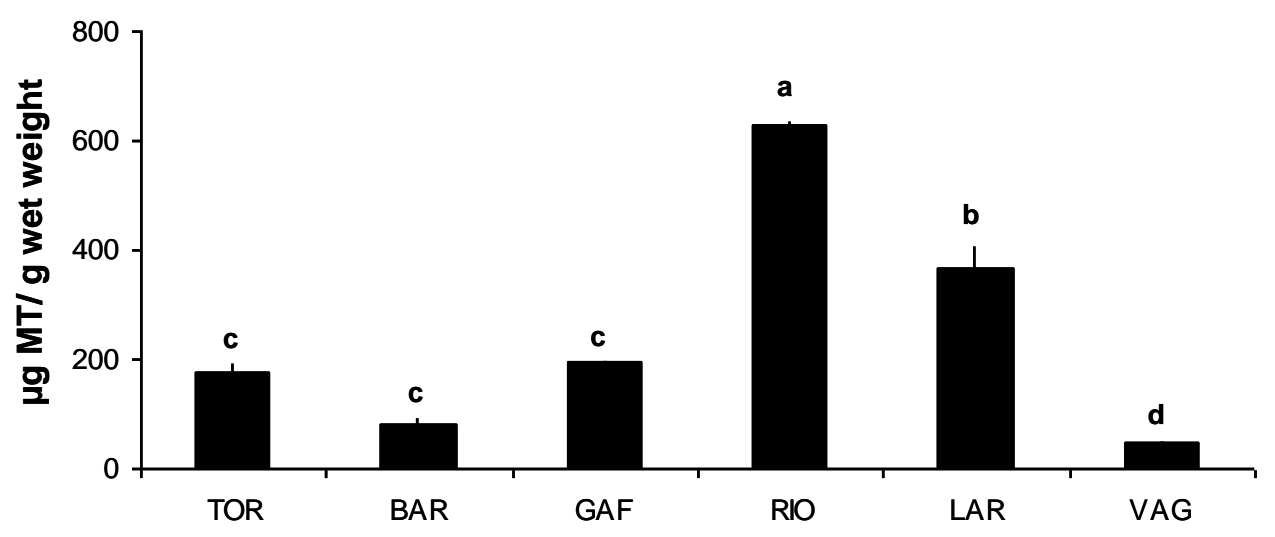


Figure 3
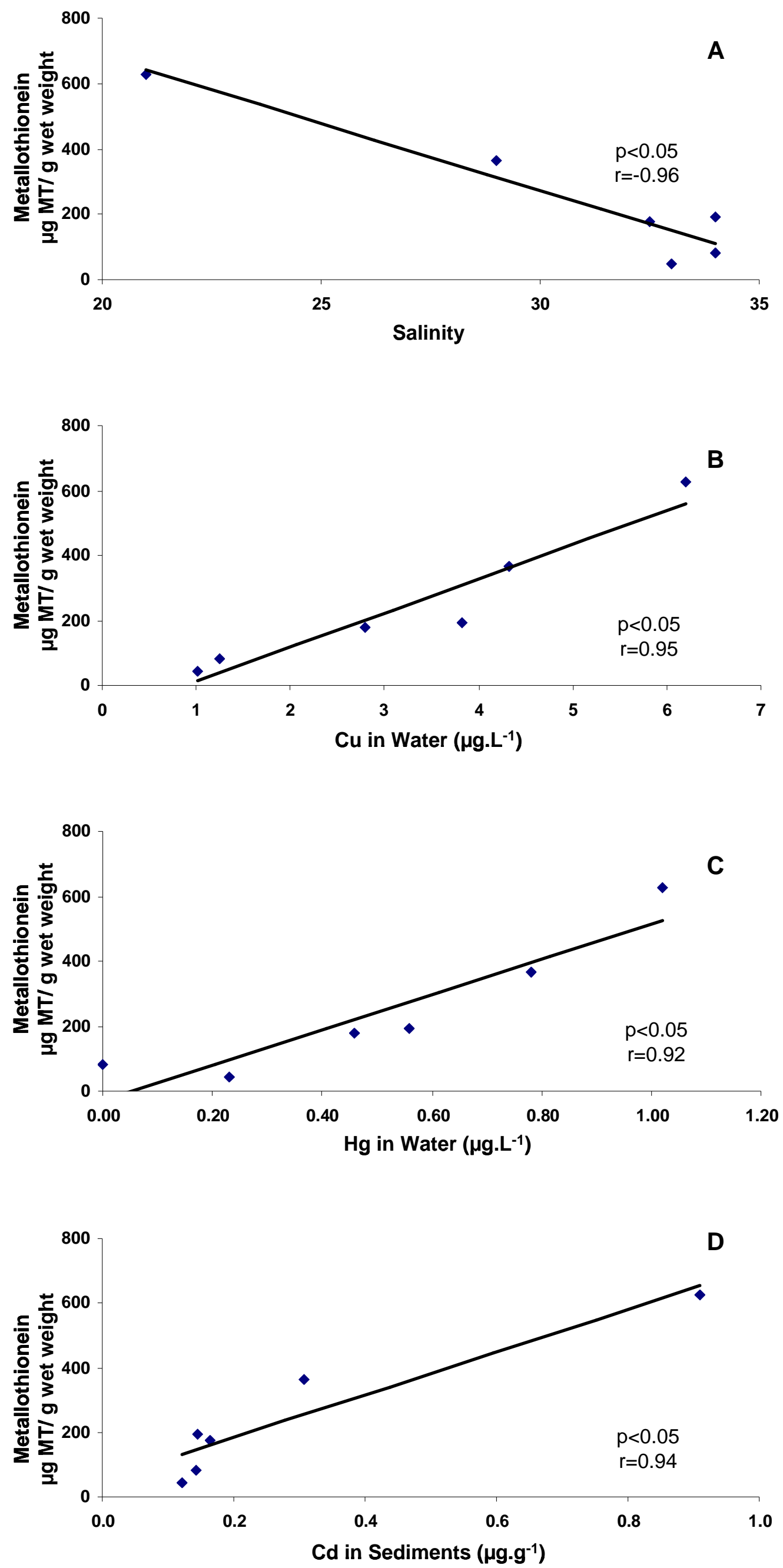
Table I

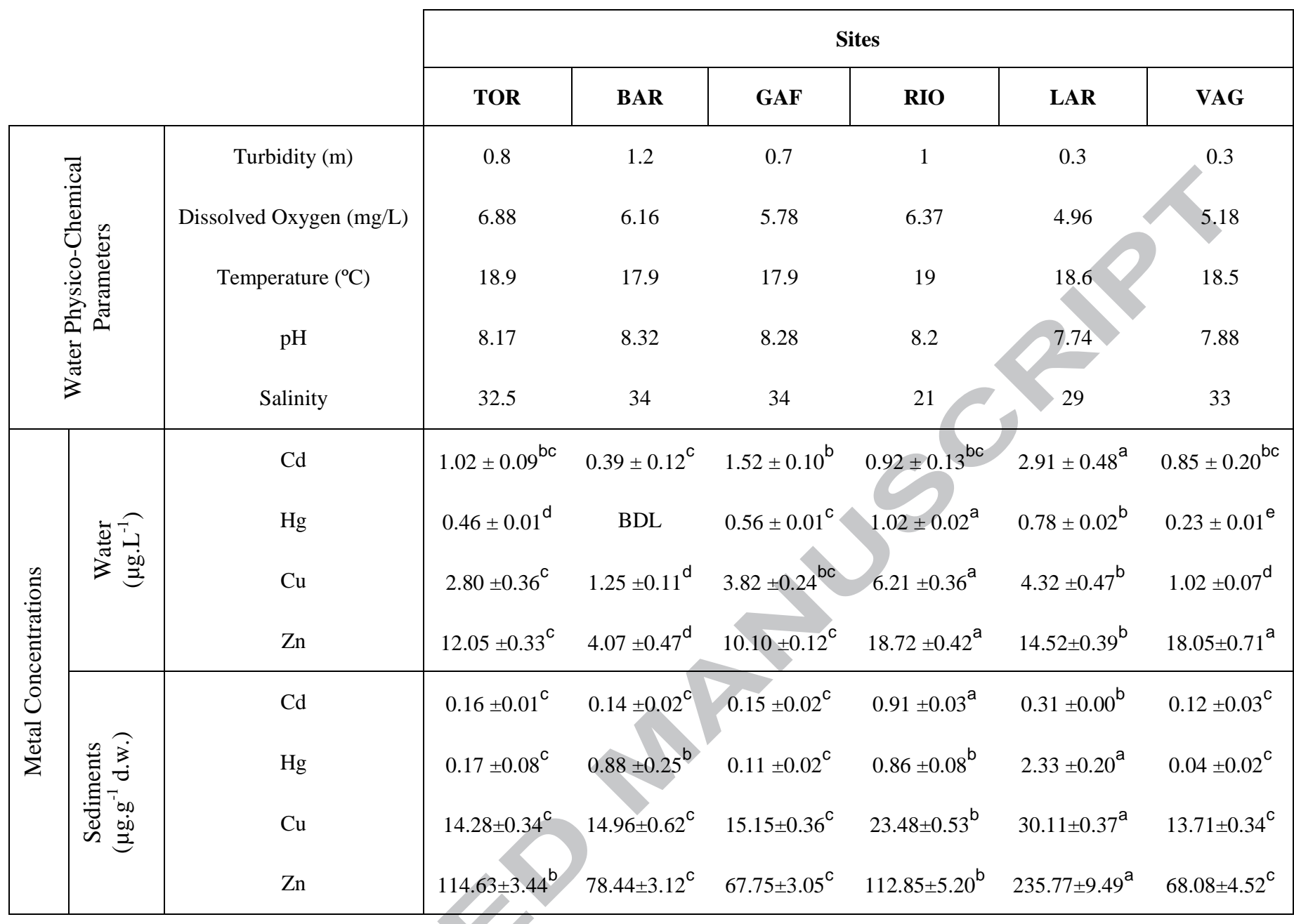


Table II

\begin{tabular}{|l|c|c|c|}
\hline & \multicolumn{3}{|c|}{ Component } \\
\cline { 2 - 4 } & $\mathbf{1}$ & $\mathbf{2}$ & $\mathbf{3}$ \\
\hline Salinity & $\mathbf{- 0 , 9 3 2}$ & $-0,240$ & $-0,118$ \\
Cd in Sediments & $\mathbf{0 , 9 0 9}$ & 0,172 & 0,258 \\
Hg in Water & $\mathbf{0 , 8 5 0}$ & 0,399 & $-0,060$ \\
Temperature & $\mathbf{0 , 8 2 7}$ & $-0,048$ & $-0,243$ \\
Cu in Water & $\mathbf{0 , 8 0 4}$ & 0,432 & 0,193 \\
Zn in Water & $\mathbf{0 , 7 7 0}$ & $-0,139$ & $-0,614$ \\
\hline Hg in Sediments & 0,114 & $\mathbf{0 , 9 4 5}$ & $-0,110$ \\
Zn in Sediments & 0,238 & $\mathbf{0 , 8 5 5}$ & $-0,318$ \\
Cu in Sediments & 0,469 & $\mathbf{0 , 8 5 5}$ & $-0,191$ \\
Cd in Water & 0,083 & $\mathbf{0 , 7 8 9}$ & $-0,491$ \\
\hline Turbidity & 0,032 & $-0,150$ & $\mathbf{0 , 9 7 1}$ \\
pH & $-0,096$ & $-0,372$ & $\mathbf{0 , 8 9 7}$ \\
Dissolved Oxygen & 0,242 & $-0,397$ & $\mathbf{0 , 7 3 9}$ \\
\hline
\end{tabular}

